\title{
The effect of crop protection and agrotechnical factors on sunflower in the Hajdúság region
}

\author{
Szabó András - Fülöp Lajos Dóka \\ Institute of Crop Science, Faculty of Agricultural and Food Sciences and Environmental Management, Centre for Agricultural and Applied \\ Economic Sciences, University of Debrecen, H-4032 Debrecen Böszörményi str. 138.,e-mail:szabo@agr.unideb.hu
}

Kulcsszavak: sunflower, sowing time, plant density, fungicid, infection, yield

\begin{abstract}
Summary
Extreme weather conditions are becoming more and more frequent in the crop years, thus increase the risk of sunflower production. The objective of researches into plant production is to minimize these effects as much as possible. In this sense, the optimization of agrotechnological factors is of high importance. Within these factors, the appropriate crop technology (sowing time, crop density) and optimized, rational crop protection technologies are important, especially in the highly sensitive sunflower cultures. The effect of sowing time, crop density, and fungicide treatments on the yield of sunflower hybrids was analysed in different crop years in 2008 and 2009. In each case, the infection was highest with the early sowing time and at the highest crop density level $\left(65000 \mathrm{ha}^{-1}\right)$. When one fungicide treatment was applied, the rate of infection decreased compared to the control treatment. The further decrease of the infection rate was less after the second fungicide treatment.

In the humid year of 2008 the crop yield was the highest at $45000 \mathrm{ha}^{-1}$ crop density level in the control treatment and at $55000 \mathrm{crop}$ $\mathrm{ha}^{-1}$ crop density level when fungicides were applied. In the draughty year of 2009 the maximum yield was gained at $55000 \mathrm{ha}^{-1} \mathrm{crop}^{-1}$ density level in the control treatment and at $65000 \mathrm{crop} \mathrm{ha}^{-1}$ when fungicides were applied. In 2008 and 2009 as regards the crop yield, the difference between the optimal and minimal crop density levels was higher in the fungicide treatments than in the control treatment (in 2008: control: $517 \mathrm{~kg} \mathrm{ha}^{-1}$; one application of fungicides: $865 \mathrm{~kg} \mathrm{ha}^{-1}$; two applications of fungicides: $842 \mathrm{~kg} \mathrm{ha}^{-1}$ ), (in 2009: control: $577 \mathrm{~kg} \mathrm{ha}^{-1}$; one application of fungicides: $761 \mathrm{~kg} \mathrm{ha}^{-1}$; two applications of fungicides: $905 \mathrm{~kg} \mathrm{ha}^{-1}$ ).

In each and every case, the first treatment with fungicides was more effective than the second. In 2008, the highest yield was obtained with the third, late sowing time in each fungicide treatment. The differences between the crop yields with different sowing times was less than in 2009, when the results of the second treatment exceeded those of the first and third treatment in each case.
\end{abstract}

\section{INTRODUCTION, REVIEW OF SCIENTIFIC LITERATURE}

The success of sunflower production is significantly influenced by the effects of the crop year and the agrotechnical factors. We have no influence on climatic factors however, their effect can significantly be reduced by sound agrotechnology. Using the right cropping technology and crop protection methods suitable for the hybrid, the land area and the crop year decreases the yield loss caused by diseases, increases the crop yield and improves the quality. The critical factor of sunflower production is the excessive vulnerability of hybrids to infections caused by fungi. The negative effect of stalk and head infections caused by different diseases was lower in draughty years than in humid years. Even today, the climatic conditions of the crop year cannot be predicted; however, the infection rate and the yield loss caused by the unfavourable weather can significantly be reduced by adequate and well-timed crop protection technologies. Recently, the crop yields have been varying significantly, weather extremes (uneven distribution of precipitation during the crop year, draughty periods, low temperature) were rather frequent and thus increased the risk of production.

Crop density is a major agrotechnological factor in sunflower production. Using the optimal crop density level enhances the yield potential of the hybrids.

Increasing crop density (above 50-55 thousand/ha) increases the costs and decreases the crop yield (Pepó et al. 2002). Besides the climatic conditions, the crop yields and the yield safety are also influenced by the water supply and water management of the soil (Birkás et al., 2006). Within the biological optimum, the yield potential was significantly influenced by the sowing time and the crop density level (Zsombik, 2007).

The yield potential of sunflower hybrids is highly influenced by the different agrotechnical and climatic factors applied in different crop years (for e.g. crop density, sowing time, etc.) (Borbélyné et al. 2007, Zsombik 2006). Pepó and Szabó (2005) analysed the effects of agrotechnological factors at different crop density levels in sunflower. The results showed that in humid, cold crop years the yield was lower due to the higher degree of infection by stalk and head diseases. The optimal crop density level varied with the hybrids proving that in humid, cold years the optimal crop density level is determined by the resistance of the plant against stalk and head diseases. In dry years, since the spread of diseases is slower, the infection rate was lower, which was reflected in the yields and the oil yield as well. The agroclimatic factors have the most significant influence on the crop yield, while the effect of the hybrid composition was moderate. The emergence and intensity of diseases is significantly influenced by the hybrid composition, as well as the agroclimatic factors in the crop year (temperature, distribution and amount of precipitation) (Branimir et al., 2008).

The precipitation in the vegetation period has a significant influence on the emergence of the diseases as well as on the crop yield. If soil conditions are favourable, sunflower can utilize the precipitation accumulated before the vegetation period, the highest yield can be obtained in dry crop years (Borbélyné et al., 2007). Today the most 
critical factor of production technology is crop protection. Not only the weed control measures but also the prevention of diseases needs wide-range expertise. Today, the success lies in prevention and in the integrated application of chemical and agrotechnological methods. Besides the use of effective pesticides other factors, such as crop rotation, optimal nutrient supply, sound soil cultivation, optimal sowing time and crop density, control of weeds and volunteer weeds, cultivation of plant residues in the soil are of equal importance to obtain weed-free and healthy sunflower cultures. Out of the various pathogens of sunflower the most dangerous ones are powdery mildew (Plasmophara halstedii), Diaporthe stem canker (Diaporthe helianthi), white mould (Sclerotinia sclerotiorum) and grey mould (Botrytis cinerea). The origin of these diseases is the infected soil, and the disease development is conduced by temperate weather or high temperature together with humid weather conditions (Goór és Kissné, 1999).

\section{Material and methods}

The experiment was carried out at the Látókép Plant Cultivation Research Site of the Debrecen University. The site is about $15 \mathrm{~km}$ from Debrecen, near the route 33 on the loess ridge of the Hajdúság region. Its physical characteristics are that of semi-compacted clay category, the plasticity index of Arany is 43 .

Examining the water management features of the soil we found that they are favourable, as characteristic of chernozem soils. According to the Várallyay classification it is ranked in category IV i.e. it has good water management and water storing capacity.

Crop density was set manually after the emergance of the young plant. Harvesting was done by Sampo parcel harvester applied with a special adapter. The raw yield and moisture content was measures at harvesting. The crop yields weer standardized at $8 \%$ moisture content. In both years two hybrids were examined (2008: NK Delfi, PR64D82; 2009: Petunia, NK Kondi).

The design of the experiment was random-block, it was conducted in 4 repetitions. Three different sowing times were used (in 2008.: 1st sowing time: 200829 March.; 2nd sowing time: 200809 April; 3rd sowing time: 2008 04 May; in 2009: 1st sowing time: 2009 31 March.; 2nd sowing time: 200918 April.; 3rd sowing time: 200905

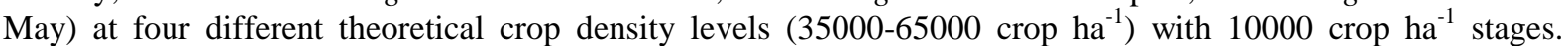
Fungicide treatment was applied at the 8-leaf stage on plots where fungicide treatment was applied once, and at the 8-leaf-stage and the flowering stages on plots with two fungicide treatments. The applied pesticides were Pictor $\left(0,51 \mathrm{ha}^{-1}\right)$ in 2008 and Tanos $\left(0,4 \mathrm{~kg} \mathrm{ha}^{-1}\right)$ in 2009 . We have reported the fenological, fenometrical, agronomical and pathological features of hybrids in four repetitions.

In 2008, the amount of precipitation was high, at the same time the weather was cold, which had a negative effect on sunflower hybrids. The amount of precipitation in the cropping season $(441.7 \mathrm{~mm})$ was much higher than the 30 year average $(307.1 \mathrm{~mm})$, while the average temperature increased the 30 year average by $1{ }^{\circ} \mathrm{C}$. In each month in the cropping season the amount of precipitation was high, in June and July it even increased 140 $\mathrm{mm}$.

In 2009, the precipitation in the cropping season was only third of the previous year's (147.1 mm) and around half of the 30 year average. The distribution of the precipitation was very uneven. The amount of precipitation was significant in June $(96.6 \mathrm{~mm})$, however, in each month of the cropping season the amount of rainfall was very low. The amount of rain was $126.6 \mathrm{~mm}$ in the first quarter of the cropping season, which counted for $85 \%$ of the amount fell in the vegetation period. In 2009 the average temperature of the cropping season was $1.6^{\circ} \mathrm{C}$ higher than in the previous year, and it was $2.6^{\circ} \mathrm{C}$ higher than the 30 year average. The average temperature in the first three months of the vegetation period (April, May, July) was $1.1^{\circ} \mathrm{C}$ higher than the same value in 2008 , while the average temperature of the first two months (July, August) was $2.5^{\circ} \mathrm{C}$ higher than in 2008 (table $1-2$.). 
The amount of rainfall in the examined years

(Debrecen-Látókép, 2007-2009.)

\begin{tabular}{|c|c|c|c|c|c|c|c|c|c|c|c|}
\hline \multicolumn{12}{|c|}{ 2007-2008 (mm) } \\
\hline october & november & december & january & february & may & april & may & june & july & august & Total \\
\hline 71,4 & 40,9 & 29,8 & 26,4 & 4,6 & 41,7 & 74,9 & 47,6 & 140,1 & 144,9 & 34,2 & \multirow{3}{*}{656,5} \\
\hline \multirow{2}{*}{\multicolumn{6}{|c|}{214,8}} & \multicolumn{5}{|c|}{441,7} & \\
\hline & & & & & & \multicolumn{3}{|c|}{262,6} & \multicolumn{2}{|c|}{179,1} & \\
\hline \multicolumn{12}{|c|}{ 2008-2009 (mm) } \\
\hline october & november & december & january & february & may & april & may & june & july & august & Total \\
\hline 16,1 & 19,8 & 52,2 & 29,5 & 44 & 41,6 & $\mathbf{9 , 9}$ & 20,1 & 96,6 & 9,2 & 11,3 & \multirow{3}{*}{350,3} \\
\hline \multirow{2}{*}{\multicolumn{6}{|c|}{203,2}} & \multicolumn{5}{|c|}{147,1} & \\
\hline & & & & & & \multicolumn{3}{|c|}{126,6} & \multicolumn{2}{|c|}{20,5} & \\
\hline
\end{tabular}

Table 2 .

The temperature profile int he examined years

(Debrecen-Látókép, 2007-2009.)

\begin{tabular}{|c|c|c|c|c|c|}
\hline \multicolumn{6}{|c|}{ 2007-2008 $\left({ }^{\circ} \mathrm{C}\right)$} \\
\hline april & may & june & july & august & Average \\
\hline 11,4 & 16,8 & 20,6 & 20,4 & 20,6 & \multirow{3}{*}{18,0} \\
\hline \multicolumn{5}{|c|}{18,0} & \\
\hline \multicolumn{3}{|c|}{16,3} & \multicolumn{2}{|c|}{20,5} & \\
\hline \multicolumn{6}{|c|}{ 2008-2009 $\left({ }^{\circ} \mathrm{C}\right)$} \\
\hline april & may & june & july & august & Average \\
\hline 14,9 & 17,4 & 19,8 & 23,4 & 22,6 & \multirow{3}{*}{19,6} \\
\hline \multicolumn{5}{|c|}{19,6} & \\
\hline \multicolumn{3}{|c|}{17,4} & \multicolumn{2}{|c|}{23,0} & \\
\hline
\end{tabular}

\section{EVALUATION OF THE RESULTS}

We have examined the effect of sowing time, crop density and different fungicide treatments on the infection and yield of sunflower hybrids.

As a result of the differences between the cropping seasons, our results showed significant differences in the agrotechnical and crop protection technologies in the two examined years. As a result of the different sowing times, crop density levels and fungicide treatments, the infection by Diaporthe and Sclerotinia, as well as by head diseases was different. In each case, the infection by head diseases, Diaporthe and Slerotinia was highest with the 1 st sowing time and at the highest crop density level. The infection rates decreased with the 2 nd and 3 rd sowing times. The humid and cold year of 2008 was favourable for the spread of fungal diseases, therefore, the infection rates were higher. On the control plots where fungicides were not applied, the infection by Diaporthe, Sclerotinia and head diseases was highest on the average of the crop density level and the sowing times (48\%, $6.5 \%, 30.8 \%$ ). One application of fungicides decreased the average infection rate of Diaporthe, Sclerotinia and head diseases by $9.0 \%, 2.8 \%$, and $9.5 \%$, respectively. The second fungicide treatment further decreased the Sclerotinia and head diseases, but the decrease was less than that was between the non-treated and the oncetreated plots $(5.7 \%, 1.5 \%)$. The infection by Diaporthe decreased by $12 \%$. On the average of the hybrids and the treatments in the experiment, the infection rate by Diaporthe, Sclerotinia and head diseases was $38 \%, 4.1 \%$, $22.6 \%$, respectively (Table 3).

Table 3 .

Infection rates in different crop protection and cultivation technologies on the average of the hybrids in 2008 (Debrecen-Látókép, 2008)

\begin{tabular}{|c|c|c|c|c|}
\hline Fungicide treatment & Sowing time & Head diseases (\%) & Sclerotinia (\%) & Diaporthe (\%) \\
\hline \multirow{5}{*}{ Control } & 1. sowing time & 41,7 & 9,6 & 57 \\
\hline & 2. sowing time & 31,8 & 6,5 & 54 \\
\hline & 3. sowing time & 18,8 & 3,3 & 34 \\
\hline & Average & 30,8 & 6,5 & 48 \\
\hline & LSD5\% & 3,9 & 0,9 & 6 \\
\hline \multirow{5}{*}{ Once treated } & 1. sowing time & 28,2 & 5,4 & 49 \\
\hline & 2. sowing time & 22,2 & 3,6 & 41 \\
\hline & 3. sowing time & 13,6 & 2,3 & 26 \\
\hline & Average & 21,3 & 3,7 & 39 \\
\hline & LSD5\% & 5,2 & 0,9 & 5 \\
\hline Twice treated & 1. sowing time & 19,9 & 2,7 & 32 \\
\hline
\end{tabular}




\begin{tabular}{|c|c|c|c|c|}
\hline & 2. sowing time & 17,4 & 2,2 & 30 \\
\hline & 3. sowing time & 9,5 & 1,7 & 20 \\
\hline & Average & 15,6 & 2,2 & 27 \\
\hline & LSD5\% & 4,3 & 0,8 & 7 \\
\hline Fungicide treatment & Plant Density & Head diseases (\%) & Sclerotinia (\%) & Diaporthe (\%) \\
\hline \multirow{6}{*}{ control } & 35000 plant hectar ${ }^{-1}$ & 24,1 & 3,4 & 37 \\
\hline & 45000 plant hectar ${ }^{-1}$ & 27,5 & 4,9 & 39 \\
\hline & 55000 plant hectar ${ }^{-1}$ & 34,7 & 8,0 & 57 \\
\hline & 65000 plant hectar ${ }^{-1}$ & 36,8 & 9,7 & 60 \\
\hline & Average & 30,8 & 6,5 & 48 \\
\hline & LSD5\% & 3,9 & 0,9 & 6 \\
\hline \multirow{6}{*}{ Once treated } & 35000 plant hectar ${ }^{-1}$ & 15,8 & 1,9 & 31 \\
\hline & 45000 plant hectar ${ }^{-1}$ & 18,9 & 2,6 & 33 \\
\hline & 55000 plant hectar ${ }^{-1}$ & 24,3 & 4,8 & 45 \\
\hline & 65000 plant hectar ${ }^{-1}$ & 26,4 & 5,7 & 47 \\
\hline & Average & 21,3 & 3,7 & 39 \\
\hline & LSD5\% & 5,2 & 0,9 & 5 \\
\hline \multirow{6}{*}{ Twice treated } & 35000 plant hectar ${ }^{-1}$ & 10,3 & 0,9 & 23 \\
\hline & 45000 plant hectar ${ }^{-1}$ & 12,8 & 1,8 & 25 \\
\hline & 55000 plant hectar ${ }^{-1}$ & 18,6 & 2,7 & 29 \\
\hline & 65000 plant hectar ${ }^{-1}$ & 20,8 & 3,2 & 31 \\
\hline & Average & 15,6 & 2,2 & 27 \\
\hline & LSD5\% & 4,3 & 0,8 & 7 \\
\hline \multicolumn{2}{|c|}{ Average of treatments } & 22,6 & 4,1 & 38,0 \\
\hline
\end{tabular}

The dry weather in 2009 decreased the formation and spread of diseases, therefore, the infection rate of the examined pathological factors was lower. On the average of the hybrids and the treatments, the infection by Diaporthe, Sclerotinia and head diseases was $17 \%, 1.4 \%$ and $12 \%$, respectively. As a result of the lower infection pressure, the effect of the fungicide treatments was less than in the previous year in case of all diseases. One application of fungicides decreased the infection by only $6 \%, 0.7 \%, 3.7 \%$ respectively. The second fungicide treatment resulted in further decrease of the infection rate (4\%, $0.3 \%$, and $3.3 \%$, respectively). As the number of treatments increased, the infection rate decreased at a lower degree (Table 4 ).

Table 4.

Infection rates in different crop protection and cultivation technologies on the average of the hybrids in 2009

(Debrecen-Látókép, 2009)

\begin{tabular}{|c|c|c|c|c|}
\hline Fungicide treatment & Sowing time & Head diseases (\%) & Sclerotinia $(\%)$ & Diaporthe (\%) \\
\hline \multirow{5}{*}{ Control } & 1. sowing time & 24,5 & 3,2 & 40 \\
\hline & 2. sowing time & 16,5 & 2,1 & 21 \\
\hline & 3. sowing time & 5,8 & 0,8 & 8 \\
\hline & Average & 15,6 & 2,0 & 23 \\
\hline & LSD5\% & 6,1 & 0,4 & 6 \\
\hline \multirow{5}{*}{ Once treated } & 1. sowing time & 18,2 & 1,9 & 30 \\
\hline & 2. sowing time & 12,7 & 1,4 & 16 \\
\hline & 3. sowing time & 4,8 & 0,6 & 6 \\
\hline & Average & 11,9 & 1,3 & 17 \\
\hline & LSD5\% & 5,4 & 0,7 & 5 \\
\hline \multirow{5}{*}{ Twice treated } & 1. sowing time & 13,3 & 1,3 & 21 \\
\hline & 2. sowing time & 9,5 & 1,0 & 12 \\
\hline & 3. sowing time & 3,1 & 0,6 & 5 \\
\hline & Average & 8,6 & 1,0 & 13 \\
\hline & LSD5\% & 2,9 & 0,5 & 7 \\
\hline Fungicide treatment & Plant Density & Head diseases $(\%)$ & Sclerotinia $(\%)$ & Diaporthe (\%) \\
\hline \multirow{6}{*}{ control } & 35000 plant hectar ${ }^{-1}$ & 10,5 & 1,4 & 18 \\
\hline & 45000 plant hectar ${ }^{-1}$ & 14,1 & 1,9 & 21 \\
\hline & 55000 plant hectar ${ }^{-1}$ & 15,3 & 2,1 & 22 \\
\hline & 65000 plant hectar ${ }^{-1}$ & 22,5 & 2,8 & 32 \\
\hline & Average & 15,6 & 2,0 & 23 \\
\hline & LSD5\% & 6,1 & 0,4 & 6 \\
\hline Once treated & 35000 plant hectar ${ }^{-1}$ & 7,8 & 0,8 & 14 \\
\hline
\end{tabular}




\begin{tabular}{|c|c|c|c|c|}
\hline & 45000 plant hectar ${ }^{-1}$ & 9,9 & 1,1 & 16 \\
\hline & 55000 plant hectar ${ }^{-1}$ & 13,0 & 1,5 & 17 \\
\hline & 65000 plant hectar ${ }^{-1}$ & 17,0 & 1,8 & 23 \\
\hline & Average & 11,9 & 1,3 & 17 \\
\hline & LSD5\% & 5,4 & 0,7 & 5 \\
\hline \multirow{6}{*}{ Twice treated } & 35000 plant hectar ${ }^{-1}$ & 5,6 & 0,7 & 10 \\
\hline & 45000 plant hectar ${ }^{-1}$ & 7,2 & 0,9 & 12 \\
\hline & 55000 plant hectar ${ }^{-1}$ & 9,4 & 1,1 & 13 \\
\hline & 65000 plant hectar ${ }^{-1}$ & 12,3 & 1,2 & 16 \\
\hline & Average & 8,6 & 1,0 & 13 \\
\hline & LSD5\% & 2,9 & 0,5 & 7 \\
\hline \multicolumn{2}{|c|}{ Average of treatments } & 12,0 & 1,4 & 17 \\
\hline
\end{tabular}

The agrotechnological factors, the crop protection technologies, as well as the crop year significantly influenced the crop yield and yield safety. Examining the effect of sowing times in 2008, we found that the later the sowing was done, the higher the yield was. On the average of the treatments the yields with the 1st, 2nd and 3rd sowing times were $4543 \mathrm{~kg} \mathrm{ha}^{-1}, 4560 \mathrm{~kg} \mathrm{ha}^{-1}$, and $4820 \mathrm{~kg} \mathrm{ha}^{-1}$, respectively. The highest average yield was obtained on plots where fungicides were applied twice with all three sowing times $\left(4818 \mathrm{~kg} \mathrm{ha}^{-1}, 4750 \mathrm{~kg} \mathrm{ha}^{-1}, 5051 \mathrm{~kg} \mathrm{ha}^{-1}\right)$. The yield difference between the 1st and 2nd sowing times was minimal $\left(17 \mathrm{~kg} \mathrm{ha}^{-1}\right)$, the yield increase between the first and third sowing times was higher $\left(273 \mathrm{~kg} \mathrm{ha}^{-1}\right)$. In the control treatments (no fungicides applied) the yield difference between the three sowing times on the average of the crop density was lower than in the treatments where fungicides were applied (the difference between the 1st and 3rd sowing time is $169 \mathrm{~kg} \mathrm{ha}^{-1}$ ). The yield increase was the highest in the treatment where fungicide was applied once on the average of the crop density levels (the difference between the 1st and 3rd sowing time is $426 \mathrm{~kg} \mathrm{ha}^{-1}$ ). The second fungicide treatment resulted smaller yield increase.. The fungicide treatments increased the effects of the sowing times as well. With the first sowing time, on the average of the crop density levels the yield increase caused by the first fungicide treatment was $398 \mathrm{~kg} \mathrm{~h}^{-1}$ compared to the control plot, while the yield increasing effect of the second treatment was $213 \mathrm{~kg} \mathrm{ha}^{-1}$, compared to the plot that was only treated with fungicides once. With the 2nd and 3rd sowing times compared to the control plot, the yield increase was singificant in the stands where fungicides were applied once $\left(655 \mathrm{~kg} \mathrm{ha}^{-1}, 522 \mathrm{~kg} \mathrm{ha}^{-1}\right)$ and minor in the stands with a second fungicide treatment $(29 \mathrm{~kg} \mathrm{ha}$ $\left.1,20 \mathrm{~kg} \mathrm{ha}^{-1}\right)$.

The optimal crop density levels were 55 thousand $\mathrm{ha}^{-1}$ with the first sowing time and 45 thousand in the second and third sowing times on the average of the sowing times. In both treatments (one or two application of fungicides) with all three sowing times, the maximum yield was obtained at 55000 plant ha $^{-1}$ on the average of the sowing times. In 2008 the difference between the optimal and minimal crop density levels was higher in case of the treated cultures that on the control plots (control: $517 \mathrm{~kg} \mathrm{ha}^{-1}$; one treatment: $865 \mathrm{~kg} \mathrm{ha}^{-1}$; two treatments: $842 \mathrm{~kg} \mathrm{ha}^{-1}$ ) (Table 5).

Table 5 .

Crop yields in different crop protection and cultivation technologies on the average of the hybrids in 2008 (Debrecen-Látókép, 2008)

\begin{tabular}{|c|c|c|c|c|c|}
\hline Fungicide treatment & Plant Density & 1. sowing time & 2. sowing time & 3. sowing time & Average \\
\hline \multirow{4}{*}{ Control } & 35000 plant hectar ${ }^{-1}$ & 4008 & 3935 & 4082 & 4008 \\
\hline & 45000 plant hectar ${ }^{-1}$ & 4419 & 4582 & 4575 & 4525 \\
\hline & 55000 plant hectar ${ }^{-1}$ & 4451 & 4379 & 4506 & 4445 \\
\hline & 65000 plant hectar ${ }^{-1}$ & 3950 & 3940 & 4342 & 4077 \\
\hline \multicolumn{2}{|c|}{ Average } & 4207 & 4209 & 4376 & 4264 \\
\hline \multicolumn{2}{|c|}{ LSD5\% } & 321 & 256 & 396 & \\
\hline \multirow{4}{*}{ Once treated } & 35000 plant hectar ${ }^{-1}$ & 4213 & 4155 & 4480 & 4282 \\
\hline & 45000 plant hectar ${ }^{-1}$ & 4675 & 4916 & 5182 & 4924 \\
\hline & 55000 plant hectar ${ }^{-1}$ & 4938 & 5115 & 5388 & 5147 \\
\hline & 65000 plant hectar ${ }^{-1}$ & 4596 & 4699 & 5076 & 4790 \\
\hline \multicolumn{2}{|c|}{ Average } & 4605 & 4721 & 5031 & 4786 \\
\hline \multicolumn{2}{|c|}{ LSD5\% } & 279 & 310 & 276 & \\
\hline \multirow{4}{*}{ Twice treated } & 35000 plant hectar ${ }^{-1}$ & 4361 & 4268 & 4549 & 4392 \\
\hline & 45000 plant hectar ${ }^{-1}$ & 4839 & 4895 & 5114 & 4949 \\
\hline & 55000 plant hectar ${ }^{-1}$ & 5137 & 5061 & 5504 & 5234 \\
\hline & 65000 plant hectar ${ }^{-1}$ & 4936 & 4775 & 5040 & 4917 \\
\hline \multicolumn{2}{|c|}{ Average } & 4818 & 4750 & 5051 & 4873 \\
\hline \multicolumn{2}{|c|}{ LSD5\% } & 379 & 271 & 311 & \\
\hline \multicolumn{2}{|c|}{ Average of treatments } & 4543 & 4560 & 4820 & 4641 \\
\hline
\end{tabular}


In 2009, the highest yield $\left(5090 \mathrm{~kg} \mathrm{ha}^{-1}\right)$ was obtained with the 2 nd sowing time on the average of the treatments. Both the earlier and the later sowing time caused yield loss $\left(3731 \mathrm{~kg} \mathrm{ha}^{-1}, 4741 \mathrm{~kg} \mathrm{ha}^{-1}\right)$. The same tendency was experienced on the average of the crop density levels in all three treatments (control, one treatment, two treatments). Compared to the 1st sowing time, the yield increase with the 2nd sowing time ranged between 1333 $\mathrm{kg} \mathrm{ha}^{-1}-1383 \mathrm{~kg} \mathrm{ha}^{-1}$. Compared to the 2 nd sowing time, the yield decrease with the 3rd sowing time ranged between $328 \mathrm{~kg} \mathrm{ha}^{-1}$ and $354 \mathrm{~kg} \mathrm{ha}^{-1}$. On the average of the sowing times and crop density levels, the highest yield $\left(4747 \mathrm{~kg} \mathrm{ha}^{-1}\right)$ was obtained on the plot where fungicides were applied twice and it was lowest (4247 kg ha ${ }^{-1}$ ) in the control stands. Due to the lower infection rate the yield increasing effect of the single fungicide application was lower than in the humid cropyear of $2008\left(314 \mathrm{~kg} \mathrm{ha}^{-1}, 316 \mathrm{~kg} \mathrm{ha}^{-1}, 324 \mathrm{~kg} \mathrm{ha}^{-1}\right)$ on the average of the crop density levels, but the effect of the 2 nd fungicide treatment was significant with the 2nd and 3 rd sowing times. Due to the effects of the cropping years, the maximum yield was realized at 55 thousand ha $^{-1}$ with all three sowing times in the control treatment, at 65 thousand $\mathrm{ha}^{-1}$ with the 1 st and 2 nd sowing times on plots treated once and at 55 thousand $\mathrm{ha}^{-1}$ with the $3 \mathrm{rd}$ sowing time. On plots where fungicides were applied twice, the optimal crop density level was 65 thousand ha $^{-1}$ with all three sowing times. In 2009 , the difference between the optimal and minimal crop density levels in the fungicide treatments on the average of the sowing times was higher than in the control group (control: $577 \mathrm{~kg} \mathrm{ha}^{-1}$; one treatment: $761 \mathrm{~kg} \mathrm{ha}^{-1}$; second treatment: $905 \mathrm{~kg} \mathrm{ha}^{-1}$ ). The yield was the highest at 65 thousand $\mathrm{ha}^{-1}$ crop density level with the 2 nd sowing time with two fungicide applications (Table 6).

Crop yields in different crop protection and cultivation technologies on the average of the hybrids in 2009

(Debrecen-Látókép, 2009)

\begin{tabular}{|c|c|c|c|c|c|}
\hline Fungicide treatment & Plant Density & 1. sowing time & 2. sowing time & 3. sowing time & Average \\
\hline \multirow{4}{*}{ control } & 35000 plant hectar ${ }^{-1}$ & 3120 & 4546 & 4181 & 3949 \\
\hline & 45000 plant hectar ${ }^{-1}$ & 3439 & 4787 & 4476 & 4234 \\
\hline & 55000 plant hectar ${ }^{-1}$ & 3760 & 5086 & 4731 & 4526 \\
\hline & 65000 plant hectar ${ }^{-1}$ & 3552 & 4786 & 4504 & 4280 \\
\hline \multicolumn{2}{|c|}{ Average } & 3468 & 4801 & 4473 & 4247 \\
\hline \multicolumn{2}{|c|}{ LSD5\% } & 402 & 402 & 402 & \\
\hline \multirow{4}{*}{ Once treated } & 35000 plant hectar ${ }^{-1}$ & 3336 & 4635 & 4374 & 4115 \\
\hline & 45000 plant hectar ${ }^{-1}$ & 3666 & 5006 & 4716 & 4462 \\
\hline & 55000 plant hectar ${ }^{-1}$ & 3984 & 5433 & 5079 & 4832 \\
\hline & 65000 plant hectar ${ }^{-1}$ & 4143 & 5499 & 4987 & 4876 \\
\hline \multicolumn{2}{|c|}{ Average } & 3782 & 5143 & 4789 & 4571 \\
\hline \multicolumn{2}{|c|}{ LSD5\% } & 426 & 426 & 426 & \\
\hline \multirow{4}{*}{ Twice treated } & 35000 plant hectar ${ }^{-1}$ & 3356 & 4813 & 4504 & 4224 \\
\hline & 45000 plant hectar ${ }^{-1}$ & 3861 & 5182 & 4940 & 4661 \\
\hline & 55000 plant hectar ${ }^{-1}$ & 4187 & 5580 & 5160 & 4976 \\
\hline & 65000 plant hectar ${ }^{-1}$ & 4372 & 5732 & 5285 & 5129 \\
\hline \multicolumn{2}{|c|}{ Average } & 3944 & 5327 & 4972 & 4747 \\
\hline \multicolumn{2}{|c|}{ LSD5\% } & 415 & 415 & 415 & \\
\hline \multicolumn{2}{|c|}{ Average of treatments } & 3731 & 5090 & 4744 & 4522 \\
\hline
\end{tabular}

\section{CONCLUSIONS}

Based on the average values of the examined two years, we found that the crop year, the crop density, the sowing time and the fungicide treatments are in interaction and thus strenghten or weaken the influence of one another. Table 1 and 2 reveils that in humid years the maximum yield can be obtained at lower crop density levels (45000-55000 ha ${ }^{-1}$ ) while in dry cropyears higher crop density levels can be used (55000-65000 ha $\left.{ }^{-1}\right)$. The application of fungicides allows of using higher crop density levels. In 2008 the yield of the control plots was highest at $45000 \mathrm{ha}^{-1}$ while in plots with one or two fungicide application it was $55000 \mathrm{ha}^{-1}$. The tendency was the same in 2009 with the difference that on the control plots the maximum yield was obtained at $55000 \mathrm{ha}^{-1}$ $\left(4526 \mathrm{~kg} \mathrm{ha}^{-1}\right)$ crop density level, while on the treated plots it was $\left(4876 \mathrm{~kg} \mathrm{ha}^{-1}, 5129 \mathrm{~kg} \mathrm{ha}^{-1}\right)$. In 2008-2009, as 
regards the crop yields, the difference between the optimal and minimal crop density levels was higher on the average of the sowing times than in the control treatment (2008: control: $517 \mathrm{~kg} \mathrm{ha}^{-1}$; one treatment: $865 \mathrm{~kg} \mathrm{ha}^{-1}$; second treatment: $\left.842 \mathrm{~kg} \mathrm{ha}^{-1}\right)$, (2009: control: $577 \mathrm{~kg} \mathrm{ha}^{-1}$; one treatment: $761 \mathrm{~kg} \mathrm{ha}^{-1}$; second treatment: $905 \mathrm{~kg}$ $\mathrm{ha}^{-1}$ ). However, the efficiency of the fungicide treatments is different. In humid cropyears the effect of one application of fungicides is better than in dry cropyears. The modifying effect of fungicide treatments on the yield varied with the different sowing times as well. In 2008 on the avereage of the sowing times, compared to the control treatment, the yield increase of the first fungicide treatment was $522 \mathrm{~kg} \mathrm{ha}^{-1}$ on plots with one application, and only $87 \mathrm{~kg} \mathrm{ha}^{-1}$ on plots with two applications. In 2009 the average yield increase caused by one fungicide application was lower $\left(324 \mathrm{~kg} \mathrm{ha}^{-1}\right)$. Thanks to the substantial amount of precipitation in June, the further yield increase on the plots with two fungicide treatments was higher than in the previous year. In 2008 due to the high amount of rainfall the different sowing times caused no significant differences in the yields. This year the yield average was highest with the 3rd sowing time on plots with two fungicide treatments. Due to the draught in April, in 2009 the yield of the 1st sowing time was well below that of the 2nd and 3rd sowing times. The highest yield was obtained with the 2nd sowing time. The average yield increase was $1383 \mathrm{~kg} \mathrm{ha}^{-1}$. Compared to the 2 nd sowing time, the yield reduction was $355 \mathrm{~kg} \mathrm{ha}^{-1}$ with the $3 \mathrm{rd}$ sowing time. In 2009, these yields were significantly lower (17 kg ha $\left.{ }^{-1}, 259 \mathrm{~kg} \mathrm{ha}^{-1}\right)$ (Figure 1-2).

Figure 1.: Crop yields in different crop protection and cultivation technologies on the average of the hybrids in 2008 (Debrecen-Látókép, 2008)

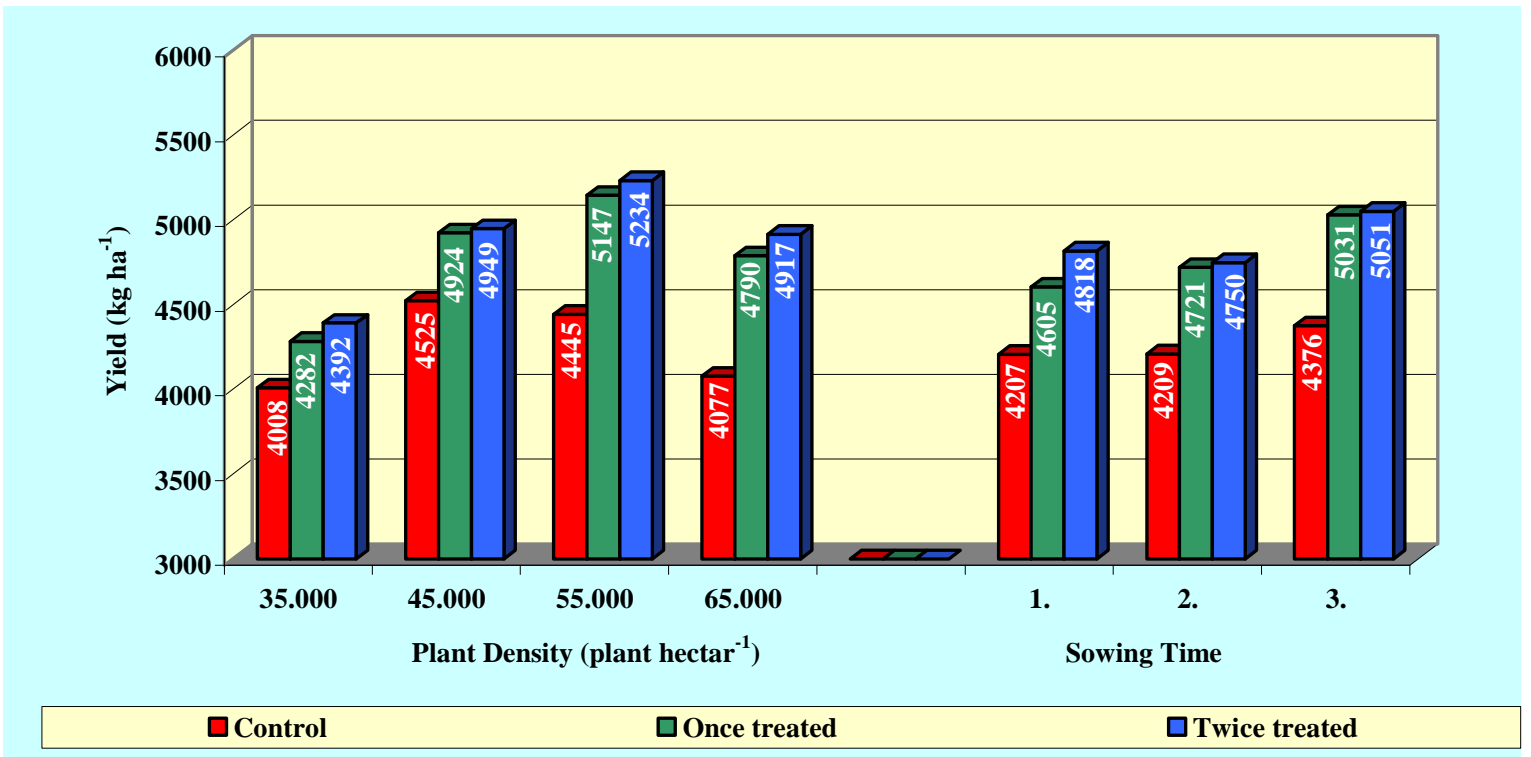

Figure 2.: Crop yields in different crop protection and cultivation technologies on the average of the hybrids in 2009 (Debrecen-Látókép, 2009) 


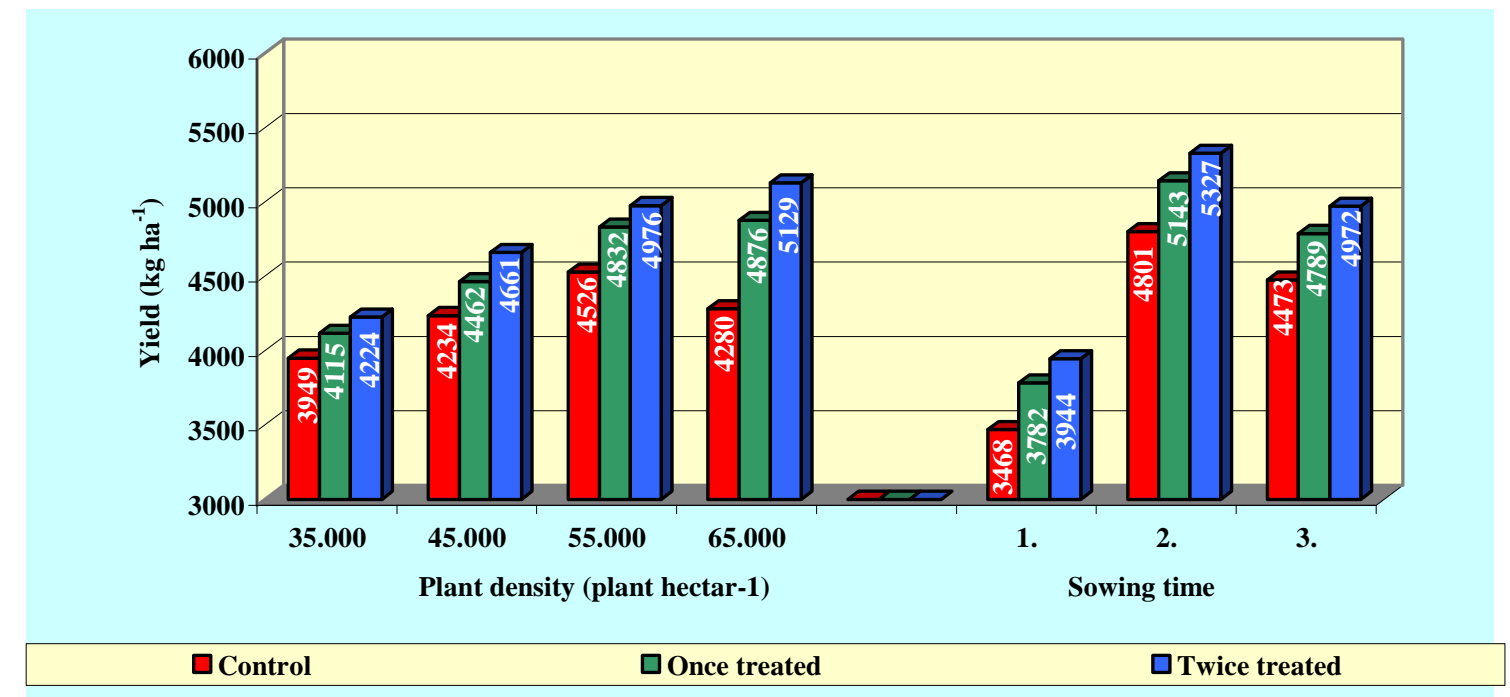

\section{REFERENCES}

Borbélyné Hunyadi É - Cajbók J. - Lesznyák M. 2007: Relations between the yield of sunflower and the characteristics of the cropyear. Cereal Research Communications, 35: 2. 285-288.

Borbélyné Hunyadi É. - Csajbók J. -Lesznyák. M. 2007: Relations between the yield of sunflower and the characteristics of the cropyear. Cereal Research Communications. 35. 2. 285-289.

Branimir S. - Jasenka C. - Ruza P. - Karolina V., 2008: Influence of climate conditions on grain yield and appearance of white rot (sclerotinia sclerotiorum) in field experiments with sunflower hybrids. Cereal Research Communications. 36. 63-66.

Goór SZ. - Kiss I-né (1999): A sikeres napraforgó termesztés alapja az igényes technológia. Gyakorlati Agrofórum. 10. 12. 9-14.

Pepó P. - Borbélyné Hunyadi É. - Zsombik L. (2002): A napraforgó-termesztés agrotechnikai fejlesztési lehetőségei. Agrofórum, 13. 1. 1922. p.

Pepó P. - Szabó A. 2005: Effect of agrotechnical and meeorological factors on yield formation in sunflower production. Cereal Research Communications. 33: 1. 49-52.

Pepó P. (1999): A genotípus szerepe a napraforgó termesztésben. V. Növénynemesítési Tudományos napok. 95. Budapest.

Zsombik L. 2006: Effect of sowing time on the oil content of different sunflower hybrids. Cereal Research Communications, 34: 1. 725-728.

Zsombik L. 2007: Effect of sowing time on yield and oil content of sunflower hybrids in Hajdúság. Cereal Research Communications, 35: 2. 1349-1352. 